\title{
ENSO impact on hydrology in Peru
}

\author{
W. S. Lavado-Casimiro ${ }^{1,2}$, O. Felipe ${ }^{1}$, E. Silvestre ${ }^{1}$, and L. Bourrel ${ }^{3}$ \\ ${ }^{1}$ Servicio Nacional de Meteorología e Hidrología, Lima, Peru \\ ${ }^{2}$ Universidad Nacional Agraria La Molina, Lima, Peru \\ Correspondence to: W. S. Lavado-Casimiro (wlavado@senamhi.gob.pe)
}

Received: 18 May 2011 - Revised: 4 September 2011 - Accepted: 1 October 2012 - Published: 2 April 2013

\begin{abstract}
The El Niño and La Niña impacts on the hydrology of Peru were assessed based on discharge data (19682006) of 20 river catchments distributed over three drainage regions in Peru: 14 in the Pacific Coast (PC), 3 in the Lake Titicaca (TL) region, and 3 in the Amazonas (AM).

To classify the El Niño and La Niña events, we used the Southern Oscillation Index (SOI) based on hydrological years (September to August). Using the SOI values, the events were re-classified as strong El Niño (SEN), moderate El Niño (MEN), normal years (N), moderate La Niña (MLN) and strong La Niña (SLN).

On average during the SEN years, sharp increases occurred in the discharges in the north central area of the PC and decreases in the remaining discharge stations that were analyzed, while in the years of MEN events, these changes show different responses than those of the SEN. During the years classified as La Niña, positive changes are mostly observed in the majority of the stations in the rivers located in the center of Peru's Pacific Coast. Another important result of this work is that the Ilave River (south of the Titicaca watershed) shows higher positive (negative) impacts during La Niña (El Niño) years, a fact that is not clearly seen in the rivers of the northern part of the Titicaca watershed (Ramis and Huancane rivers).
\end{abstract}

\section{Introduction}

Strong El Niño Southern Oscillation (ENSO) events like 1982-1983 and 1997-1998 have induced the greatest impacts on the Peruvian economy as a result of the disasters caused by the floods and droughts. Thus, according to OPS (2000), direct losses caused by ENSO extreme events during 1997-1998 were estimated at US\$ 1000 million, of which
800 million were estimated for the northern $\mathrm{PC}$ as a result of heavy rains, and 200 million were estimated for the southern Andes region due to the effects of droughts. The economic impact of these disasters was reflected in a significant reduction of the gross domestic product (GDP) up to $12 \%$.

The ENSO phenomenon is a primary mode of seasonal climatic variability, mainly in the tropics (Ropelewski and Halpert, 1987). The ENSO is a warming of the tropical Pacific Ocean and it has a great influence on weather patterns in several parts of the world.

In normal conditions, a mass of warm surface water extends into the westernmost part of the tropical Pacific Ocean, while the ocean surface is cooler on the Ecuadorian and northern Peruvian coast. This distribution of water is caused by the east-westerly trade winds (that prevail in this part of the Ocean) running east to west and drag warm surface water westward. This shift allows surface water and cold deep water to surface off the coast of South America (Humboldt Current). This current carries nutrients from the bottom; fish populations grow and form good fishing in this area. However, with every cycle of this shift ( $\sim$ from 4 to 8 yr), the system of trade winds weakens while the mass of water is heated 3 to $7^{\circ} \mathrm{C}$ higher than normal. This phenomenon, which involves changes in the ocean and the atmosphere, is known as El Niño, while contrary anomalies described above are known as La Niña.

The impacts of the ENSO have been linked to hydroclimatic anomalies around the world. A complete analysis by Chiew and McMahon (2002) indicates a clear relationship between ENSO and river discharges: regionally significant and consistent teleconnections between ENSO and discharges are identified in Australia and New Zealand, South and Central America, and moderately significant signals are identified in parts of Africa and North America. 
Table 1. Hydrometric stations used in this study and their main characteristics. Lat.: Latitude; Lon.: Longitude; Dr. Ar.: Drainage area; Q: Discharge; Esp. Q: Specific discharge; VC: Variation coefficient; Pte.: Bridge. PQ: rivers of the Pacific Coast region; TQ: rivers of Lake Titicaca region: AQ: rivers of the Amazonas region.

\begin{tabular}{lllllrrrrr}
\hline Station & River & Code & $\begin{array}{l}\text { Lat. } \\
\left({ }^{\circ} \mathrm{S}\right)\end{array}$ & $\begin{array}{l}\text { Lon. } \\
\left.{ }^{\circ} \mathrm{O}\right)\end{array}$ & $\begin{array}{r}\text { Altitude } \\
(\mathrm{m} \mathrm{s.n.m} .)\end{array}$ & $\begin{array}{r}\text { Dr. Ar. } \\
\left(\mathrm{km}^{2}\right)\end{array}$ & $\begin{array}{r}\text { Q } \\
\left(\mathrm{m}^{3} \mathrm{~s}^{-1}\right)\end{array}$ & $\begin{array}{r}\text { Esp. Q } \\
\left(\mathrm{L} \mathrm{s}^{-1} \mathrm{~km}^{2}\right)\end{array}$ & $\begin{array}{r}\text { VC } \\
\text { El Tigre }\end{array}$ \\
Batan & Tumbes & PQ-1 & 3.72 & 80.47 & 40 & 4802 & 117 & 24.4 & 0.8 \\
Quirihuac & Zaña & PQ-2 & 6.8 & 79.29 & 260 & 681 & 7 & 11.0 & 0.6 \\
Huacapongo & Viru & PQ-3 & 8.08 & 78.87 & 200 & 1918 & 8 & 4.4 & 0.9 \\
Condorcerro & Santa & PQ-4 & 8.38 & 78.67 & 280 & 941 & 4 & 3.7 & 1.2 \\
Santo Domingo & Chancay-Huaral & PQ-5 & 8.66 & 78.26 & 477 & 10353 & 135 & 13.1 & 0.3 \\
Larancocha & Chillon & PQ-7 & 11.38 & 77.05 & 697 & 1881 & 18 & 9.4 & 0.4 \\
Chosica & Rimac & PQ-8 & 11.93 & 76.69 & 906 & 2339 & 31 & 5.1 & 0.4 \\
La Capilla & Mala & PQ-9 & 12.52 & 76.5 & 424 & 2141 & 15 & 13.4 & 0.2 \\
Socsi & Cañete & PQ-10 & 13.03 & 76.2 & 330 & 6003 & 49 & 7.1 & 0.5 \\
Pte. Ocoña & Ocoña & PQ-11 & 16.42 & 73.12 & 122 & 16646 & 69 & 8.1 & 0.5 \\
Huatiapa & Majes & PQ-12 & 16 & 72.47 & 699 & 13651 & 85 & 4.2 & 0.5 \\
La Tranca & Sama & PQ-13 & 17.73 & 70.48 & 620 & 1993 & 3 & 6.2 & 0.3 \\
Aguas Calientes & Caplina & PQ-14 & 17.85 & 70.12 & 130 & 569 & 1 & 1.3 & 0.6 \\
Pte. Ramis & Ramis & TQ-1 & 15.26 & 69.87 & 385 & 16229 & 75 & 1.5 & 0.3 \\
Pte. Huancane & Huancane & TQ-2 & 15.22 & 69.79 & 386 & 3714 & 20 & 4.6 & 0.3 \\
Pte. Ilave & Ilave & TQ-3 & 16.09 & 69.63 & 385 & 8714 & 39 & 5.3 & 0.4 \\
Mejorada & Mantaro & AQ-1 & 11.78 & 75.48 & 2819 & 17244 & 165 & 4.4 & 0.5 \\
Tamshiyacu & Amazonas & AQ-2 & 4 & 73.16 & 105 & 733596 & 32445 & 9.6 & 0.3 \\
Tabatinga & Amazonas & AQ-3 & 4.25 & 69.93 & 60 & 890308 & 37873 & 44.2 & 0.1 \\
\hline
\end{tabular}

Studies of the ENSO impacts on the river discharges along the Peruvian territory are documented mainly for the rivers of the northern Pacific Peruvian coast, where the strongest impacts have been recorded during the years 1982-1983 and 1997-1998 (OPS, 2000). During these years, floods took place in northern Peru (Waylen and Caviedes, 1986; Waylen and Poveda, 2002). The Cordillera Blanca, with glacial contribution to discharge into the Santa River basin (located in the central Pacific coast of Peru), shows Glacier Mass Balance (GMB) characterized by the ENSO events (Vuille et al., 2008). Thus, there is a negative GMB during the warm phase of ENSO (El Niño) and values above the mean GMB during the cold phase (La Niña). However, the relationship between ENSO and GMB is characterized by occasional "fall breaks", especially since the early 1970s, where El Niño is associated with values above the average GMB and La Niña with negative GMB values.

Recently, Espinoza et al. (2009) carried out a study of river discharge fluctuations over the Amazon basin, using some stations located in Peruvian territory, and showed (using a principal component analysis) that the first mode of discharge variability of several rivers in the Amazonas region is related to more (less) flow during the La Niña (El Niño) event.

Considering the economic and social ENSO impacts on the Peruvian territory and due to the limited number of studies, the National Meteorology and Hydrology Service of Peru, SENAMHI (www.senamhi.gob.pe) conducts research on the "Hydrological impacts of El Niño and La Niña in Peru".

This paper aims at describing for the first time the ENSO impacts on discharge regimes throughout the Peruvian territory. Comparing to the work by Espinoza et al. (2009), in this study we use a more detailed data set of discharges over Peru.

\section{Data}

\subsection{Southern Oscillation Index (SOI)}

The index used to characterize the El Niño and La Niña events for the present study is the Southern Oscillation Index (SOI), obtained from the Australian National Climate Centre (http://www.bom.gov.au). This index is widely used to characterize the ENSO (Xu et al., 2004). The SOI is estimated using the differences in monthly values of air pressure between Tahiti (about $150^{\circ} \mathrm{W}, 18^{\circ} \mathrm{S}$ ) and Darwin (approximately $130^{\circ} \mathrm{E}, 13^{\circ} \mathrm{S}$ ). In the literature there are various methods to estimate the SOI, but it has been proved that the difference between these methods is very small (Kawamura et al., 1998). The method used in this study is the Troup SOI, which is defined as the difference in the anomaly standardized value of sea level pressure (MSLP) between Tahiti and Darwin, expressed as follows: 
$\mathrm{SOI}=\times \frac{D_{\mathrm{MSLP}}-\bar{D}_{\mathrm{MSLP}}}{S_{\mathrm{MSLP}}}$,

where $D_{\text {MSLP }}$ is the difference between the monthly average MSLP in Tahiti and Darwin, $\bar{D}_{\text {MSLP }}$ is the mean value of $D_{\text {MSLP }}$, and $S_{\text {MSLP }}$ is the standard deviation of $D_{\text {MSLP }}$ for the 1968-2005 period.

\subsection{Discharges}

Watersheds across the Peruvian territory are distinguished due to the presence of the Andes Cordillera. The rivers that drain into the Pacific Ocean are characterized by steep slopes, they are not very long, and their rainfall and discharge peaks occur simultaneously. The rivers that flow into the Amazon River are characterized by steep slopes in the Andes and near-zero slopes in the Amazon lowlands, where they have large drainage areas. The rainfall peaks occur two months before the discharge peaks in the Amazon plains and simultaneously in the Andes, which depend on the catchments size. The Titicaca endorheic drainage is characterized by mean slopes, and because it is located in the highlands, the average response between rainfall and discharge peaks is one month.

In the present study, 20 stations with discharge data at monthly step were used: 14 stations at rivers flowing into the Pacific Coast (PC), 3 into the Titicaca Lake (TL) and 3 into the Amazonas (AM). This information was provided by the SENAMHI, except for the information from the Tabatinga station (AQ-3), which is from the National Water Agency of Brazil (www.ana.gov.br). The discharge data were analyzed and completed, providing that correlations between neighboring stations had a significance rate above $95 \%$. The discharge data period used in this study goes from September 1968 to August 2006.

Table 1 shows the stations used in this study and their main characteristics, and Fig. 1 describes the spatial location of these hydrometric stations. The rivers in the TL have a specific average discharge of $5 \mathrm{~L} \mathrm{seg}^{-1} \mathrm{~km}^{-2}$; and from the rivers located in the $\mathrm{AM}$, one is in the Andean region (Mantaro River) with a specific discharge of $5 \mathrm{~L} \mathrm{seg}^{-1} \mathrm{~km}^{-2}$ and the other two are located in the Amazon lowlands (Tamshiyacu and Tabatinga on the Amazon River) with an average specific discharge of $43 \mathrm{~L} \mathrm{seg}^{-1} \mathrm{~km}^{-2}$. For comparisons with the SOI, the normalized discharge anomalies for each month were estimated according to

$z_{i j}=\frac{Q_{i j}-\bar{Q}_{i}}{\sigma_{i}}$

where $Z_{i j}$ is the normalized anomaly value of the discharges from a given $i$ station for a $j$ month $(i=1,2, \ldots, 30 ; j=$ $1,2, \ldots, 12), Q_{i j}$ is the monthly discharge from the $i$ station for our period of analysis and $\sigma_{i}$ is the standard deviation of the monthly discharge from the $i$ station during the same period.

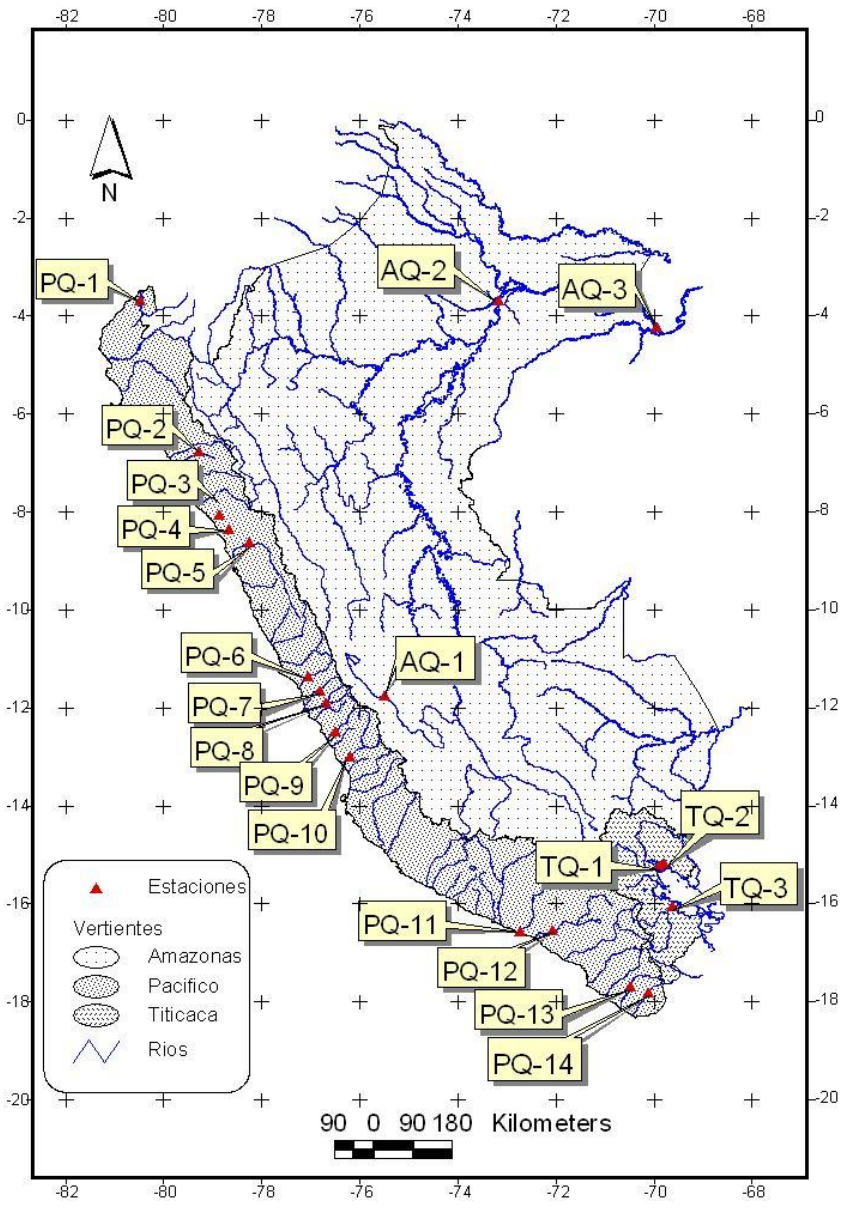

Fig. 1. Spatial location of the hydrometric stations used in this study: in the Pacific Coast (PQ) region; Lake Titicaca (TQ) region; and Amazonas (AQ) region.

\section{Results and discussions}

\subsection{El Niño, La Niña and Normal years}

In this study smoothed values for six months (moving averages) of the SOI were used, similar to the works by McKerchar et al. (1998), Chiew et al. (1998), Cluis and Laberge (2002) and Xu et al. (2004). The SOI values higher than 5 were classified as La Niña years, while SOI values lower than -5 were classified as El Niño years. Normal years correspond to years with SOI values between -5 and 5 .

In order to obtain more qualitative classification of the ENSO impacts on river discharge, the strong El Niño (SEN) years (SEN 1982/83, 1991/92 and 1997/98) were classified for SOI values lower than -10 ; the moderate El Niño (MEN) years (MEN 1972/73, 1977/78, 1986/87, 1987/88, 1992/93, 1993/94, 1994/95, 2002/03 and 2004/05) were classified for SOI values between -10 and -5 ; normal $(\mathrm{N})$ years included values between -5 and 5 . Strong La Niña (SLN 1970/71, 1973/74, 1975/76 and 1988/89) were classified for 
Table 2. Monthly statistical values for the discharges during the different periods: St.: Stations; Aver.: Average; VC: Variations Coefficient.

\begin{tabular}{|c|c|c|c|c|c|c|c|c|c|c|c|c|}
\hline \multirow[t]{2}{*}{ St. } & \multicolumn{2}{|c|}{ Historical } & \multicolumn{2}{|c|}{ SEN } & \multicolumn{2}{|c|}{ MEN } & \multicolumn{2}{|c|}{$\mathrm{N}$} & \multicolumn{2}{|c|}{ SLN } & \multicolumn{2}{|c|}{ MLN } \\
\hline & Aver. & $\mathrm{VC}$ & Aver. & $\mathrm{VC}$ & Aver. & $\mathrm{VC}$ & Aver. & $\mathrm{VC}$ & Aver. & $\mathrm{VC}$ & Aver. & VC \\
\hline PQ-1 & 120 & 1.4 & 314 & 1.1 & 112 & 1.3 & 86 & 1.2 & 127 & 1.2 & 129 & 1.1 \\
\hline PQ-2 & 7 & 1.3 & 17 & 1.5 & 6 & 0.9 & 6 & 1.0 & 8 & 0.8 & 10 & 0.8 \\
\hline PQ-3 & 8 & 1.9 & 21 & 2.0 & 7 & 1.4 & 6 & 1.6 & 8 & 1.3 & 14 & 1.4 \\
\hline PQ-4 & 4 & 2.8 & 11 & 2.4 & 2 & 1.6 & 3 & 2.6 & 3 & 1.7 & 4 & 2.1 \\
\hline PQ-5 & 136 & 0.9 & 158 & 0.9 & 141 & 0.9 & 125 & 0.9 & 144 & 0.9 & 148 & 0.9 \\
\hline PQ-6 & 18 & 1.2 & 20 & 1.2 & 15 & 1.0 & 18 & 1.3 & 18 & 0.9 & 19 & 1.2 \\
\hline PQ-7 & 6 & 1.0 & 5 & 1.0 & 6 & 0.9 & 6 & 1.0 & 5 & 1.1 & 9 & 0.9 \\
\hline PQ-8 & 31 & 0.6 & 28 & 0.6 & 32 & 0.6 & 31 & 0.6 & 27 & 0.6 & 38 & 0.6 \\
\hline PQ-9 & 15 & 1.4 & 11 & 1.5 & 15 & 1.3 & 14 & 1.5 & 21 & 1.4 & 18 & 1.3 \\
\hline PQ-10 & 49 & 1.3 & 45 & 1.1 & 46 & 1.1 & 51 & 1.4 & 47 & 1.1 & 51 & 1.0 \\
\hline PQ-11 & 69 & 1.2 & 40 & 1.4 & 61 & 1.1 & 66 & 1.3 & 89 & 1.2 & 102 & 1.2 \\
\hline PQ-12 & 85 & 1.1 & 64 & 1.0 & 81 & 1.1 & 80 & 1.0 & 105 & 1.1 & 107 & 1.1 \\
\hline PQ-13 & 3 & 1.8 & 1 & 2.1 & 2 & 1.4 & 2 & 1.8 & 3 & 1.6 & 5 & 1.6 \\
\hline PQ-14 & 1 & 0.9 & 1 & 1.4 & 1 & 0.5 & 1 & 0.7 & 1 & 0.8 & 1 & 1.0 \\
\hline TQ-1 & 75 & 1.2 & 44 & 1.1 & 79 & 1.1 & 74 & 1.2 & 86 & 1.3 & 82 & 1.2 \\
\hline TQ-2 & 20 & 1.4 & 12 & 1.1 & 21 & 1.2 & 20 & 1.4 & 22 & 1.6 & 19 & 1.5 \\
\hline TQ-3 & 39 & 1.6 & 10 & 1.0 & 30 & 1.5 & 41 & 1.5 & 50 & 1.6 & 55 & 1.7 \\
\hline AQ-1 & 165 & 0.8 & 119 & 0.6 & 170 & 0.8 & 163 & 0.8 & 196 & 0.8 & 186 & 0.8 \\
\hline AQ-2 & 32434 & 0.4 & 29608 & 0.4 & 33055 & 0.3 & 31795 & 0.4 & 35673 & 0.4 & 32621 & 0.4 \\
\hline AQ-3 & 37864 & 0.3 & 35112 & 0.3 & 38428 & 0.3 & 37208 & 0.3 & 40693 & 0.3 & 38605 & 0.3 \\
\hline
\end{tabular}

SOI values higher than 10 and moderate La Niña (MLN) years (MLN 1974/75, 1998/99, 1999/00 and 2000/01) for values between 5 and 10 .

\subsection{Impacts on discharge during the El Niño, La Niña and normal $(\mathrm{N})$ years}

\subsubsection{Impacts on the mean statistics}

Table 2 shows mean characteristics of monthly discharges for the whole historical series and for the SEN, MEN, N, SLN and MLN years. Figure 2 shows a spatial representation of the results. The main results can be described by event as follows:

- During SEN years, strong floods are clearly observed, especially in the rivers of the northern Pacific coast (PQ-1 to PQ-6), with changes of up to approximately $+200 \%$ in PQ-4; the rivers of the central and south Pacific (PQ-7 to PQ-14) as well as the rivers in the Titicaca and Amazon watershed show a decrease in their discharge during SEN years; the largest decrease occurred in TQ-3 with up to $-75 \%$ and the smallest decrease occurred in AQ-2 and AQ-3, consistent with previous studies (i.e. Aceituno and Montecinos (1993) in the highlands; Marengo et al. (1998) in the northern Pacific; and Espinoza et al. (2009) in the Amazon basin).

- During MEN years, several responses can be evidenced; in the PC, negative anomalies of the mean rates are observed in the rivers of the northern (PQ-1 to PQ-4) up to $-30 \%$ in PQ-4, as well as for the rivers PQ-6, PQ-9 to PQ-14 and TQ-3. For the later, the anomaly reaches $-20 \%$. The PQ-5, PQ-7, PQ-8, TQ-1, TQ-2 rivers and the three rivers located in the AM show positive changes, but with values that do not exceed $+5 \%$ change rate.

- During SLN and MLN years, some positive changes are observed in their mean values in all the rivers that were analyzed; the changes were more pronounced during MLN years with values of $+66 \%$ in PQ- $3,+47$ in PQ- $11,+88 \%$ in PQ-13 and $+41 \%$ in TQ-3 (Table 2).

\subsubsection{Impacts on monthly discharges}

The behavior of the monthly historical average discharge in the analyzed stations showed unimodal characteristics with a period for maximum overflow in the months of February and March in all the stations except for the stations located in the Amazon Plains (AQ-2 and AQ-3), in which maximum overflow occurred in April and May.

Using the same methodology as in the previous section, we present in Fig. 3 the changes during the El Niño years (SEN and MEN), normal $(\mathrm{N})$ years and La Niña years (SLN and MLN). In this figure, we can observe that

- During SEN years, the same rivers which present the largest positive changes in their mean value (PQ-1 to PQ-6, see above section) show the greatest changes for the months of December and January, reaching an increase of more than $400 \%$ in PQ-4. From PQ-1 to PQ-4, 

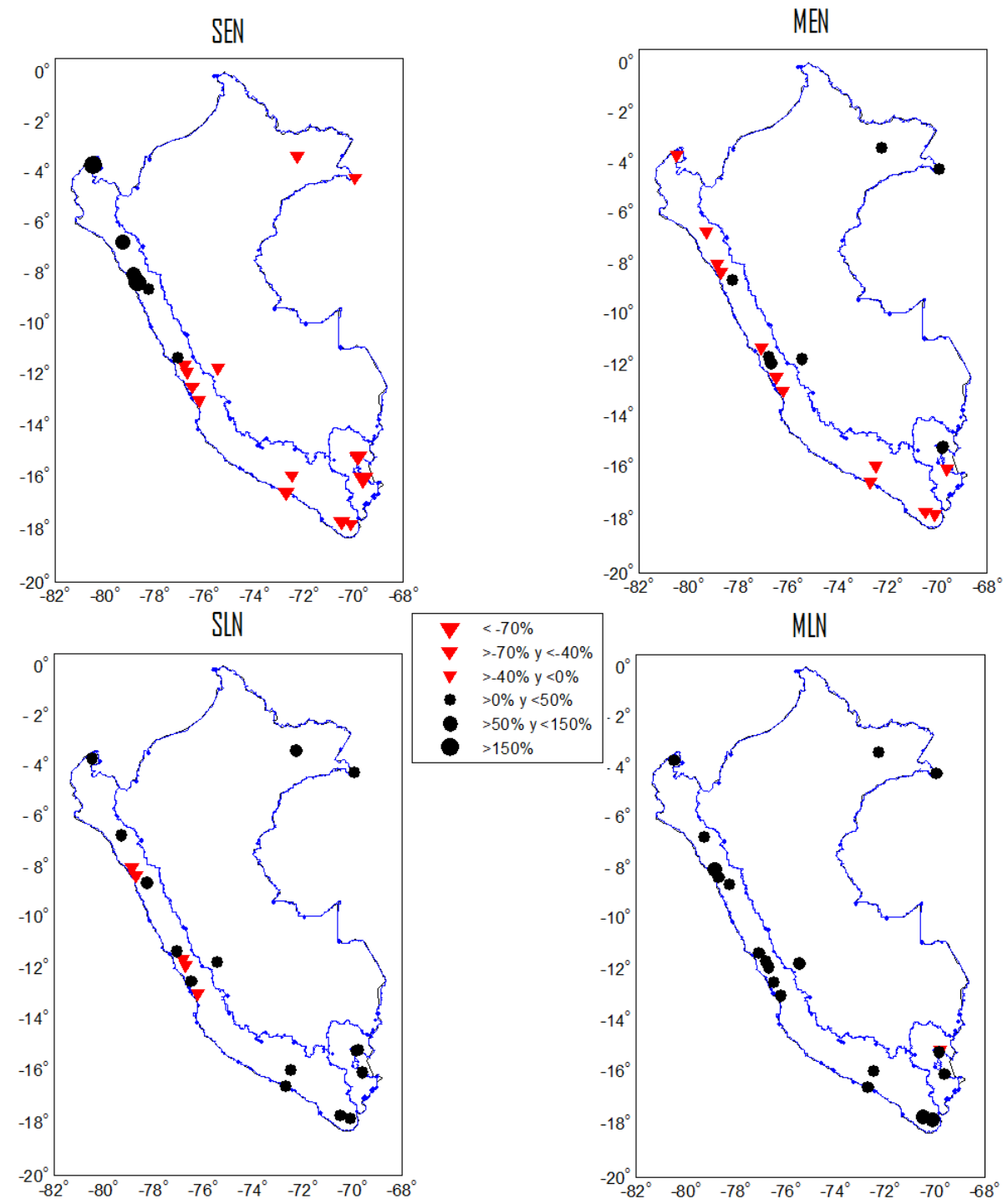

Fig. 2. Spatial distribution of rate changes in mean discharges in relation to the historical series for the different events in all the stations. The Strong El Niño years (SEN), the Moderate El Niño years (MEN), the Strong La Niña years (SLN) and the Moderate La Niña years (MLN).

positive changes were constant from December to May. The other rivers of the PC, the TL and the AM mostly show negative changes during the SEN events; thus, the largest negative changes occurred during the months of February and March, except for the rivers located in the Amazon Plain (AQ-2 and AQ-3), which showed the greatest changes in August. Among these rivers, PQ-13 (February) and TQ-3 (March) are the ones that showed the major negative changes, $-93 \%$ and $-89 \%$, respectively.

- During MEN years, the rivers that show greater positive changes in SEN years in their monthly values (December-May) (e.g. PQ-1 and PQ-4) show negative changes during these months, reaching $-57 \%$ in March in PQ-4. The same behavior was observed in other an- alyzed stations, i.e. negative changes during the MEN events. In short, during the El Niño events (SEN and MEN), it is observed that the SEN years had the greatest positive changes/anomalies for the rivers of the northern part of the PC, while all the other rivers exhibited negative anomalies in their discharge rate. The more important changes take place in the southern part of the PC (with PQ-13 Sama River as the most intense) and in the TL (with TQ-3 Ilave River as the most intense), while the MEN years are characterized by mostly negative changes in all the analyzed rivers.

- During the SLN and the MLN, similar behaviors are observed (see Fig. 3). La Niña years are characterized by showing mostly positive changes in the river discharge in Peru. They occurred mainly during flood periods 


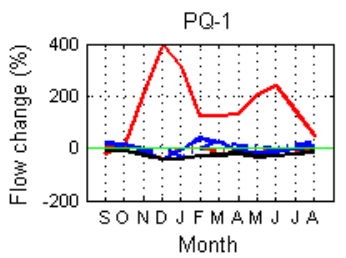

$\mathrm{PQ}-6$

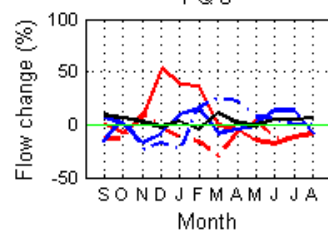

$\mathrm{PQ}-11$

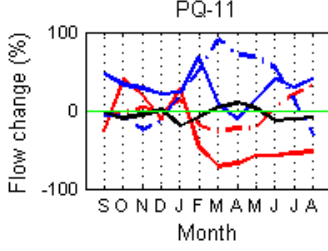

TQ-2

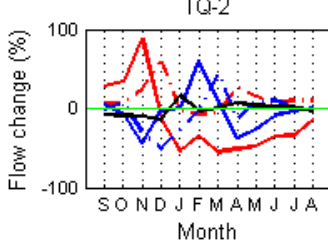

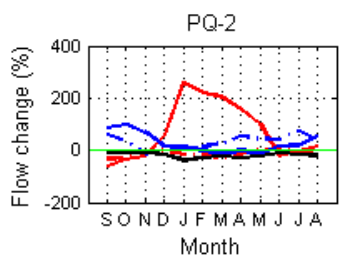

$\mathrm{PQ}-7$
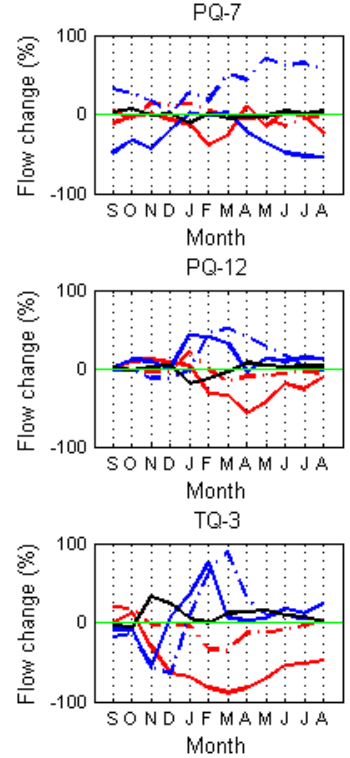
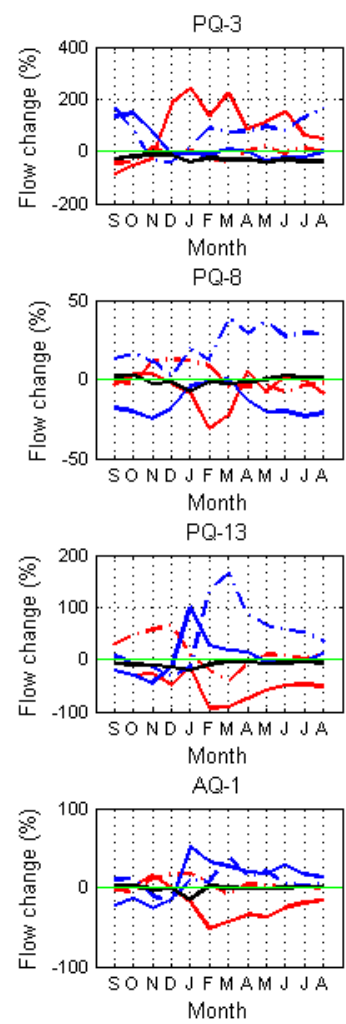

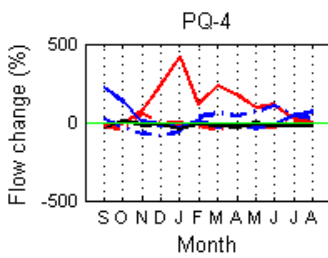

PQ-9

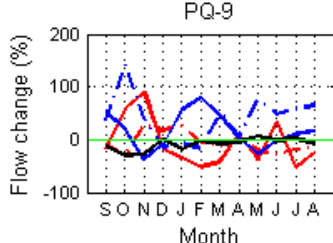

PQ-14

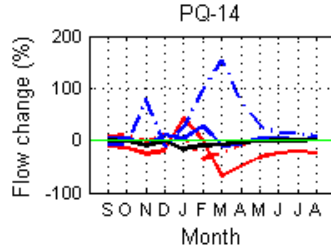

$\mathrm{AQ}-2$

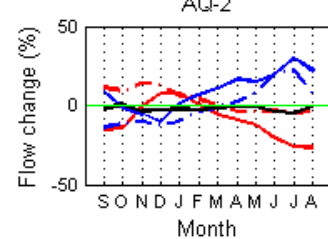

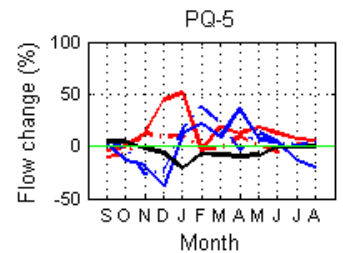

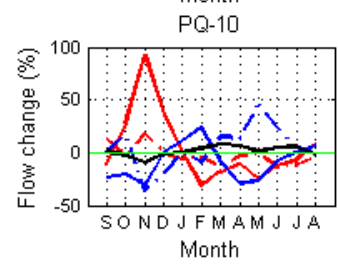

TQ-1

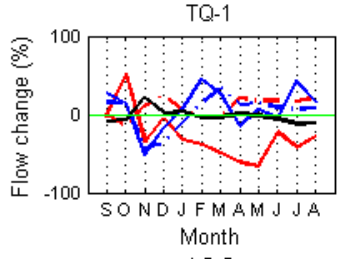

AQ-3

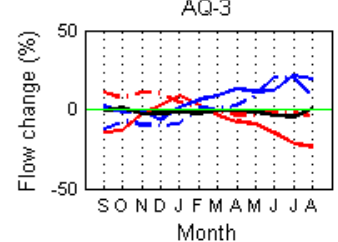

Fig. 3. Deviation of the river flow from the mean value as a function of calendar month for all stations. Red Line: SEN; Dashed-Dotted Red Line: MEN; Black Line: normal; Blue Line: MLN and Dotted Blue Line: SLN, Discharge change (\%): change in the discharges related to historical values; $x$-axis: months and y-axis: change rates (not always the same scale).

marked with positive anomalies in the MLN years, consistent in TQ-3 in the TL and in all the rivers of the AM.

\section{Conclusions and perspectives}

For the first time a study on the impact of El Niño and La Niña events on the hydrology of Peru has been carried out using 20 discharge stations distributed in three drainages regions of Peru: 14 in the Pacific Coast (PC), 3 in the Lake Titicaca (TL) and 3 in the Amazonas (AM). The studied period is from 1968 to 2006.

Based on our results, we can conclude the following:

- It can be clearly observed that during SEN years, there are sharp increases in the river discharges in the northern part of the PC, as previously reported in the literature (Waylen and Caviedes, 1986; Wells, 1987; Waylen and Poveda, 2002 and others). Here we show that such relationship between river discharge and ENSO is altered during MEN years; in particular, the discharges are reduced (negative anomalies) during MEN years in the southern part of the PC, the TL and AM being these anomalies, similar to MEN years in the southern PC and in the southern TL (Ilave River) during El Niño years.
- During La Niña years, the stations data indicate a similar variability over the whole Peruvian territory, showing positive anomalies, except in the PC were negative anomalies can be observed in the central area during SLN years.

- Investigating the seasonal evolution of the anomalies in river discharges, we note that major changes during the ENSO events occur during the wet season, namely January-March in the PC and TL, and from May to August in the rivers of the Amazon floodplain.

- Noteworthy are the 3 rivers in the TL: the Ilave River (TQ-3) located in the southern TL exhibits a comparable variability with more (less) discharge during La Niña years (El Niño), which is not observed with the other two rivers located in the northern TL.

- Overall, our results indicate that the rivers in the southern PC, TL and AM have less (more) discharge during the El Niño (La Niña) years, which is consistent with Aceituno and Montecinos (1993), Marengo et al. (1998), Dettinger et al. (2000), Espinoza et al. (2009) and some others. However, in the AM, several recent works (see Ronchail et al., 2002; Espinoza et al., 2009; Yoon and Zeng, 2010; Espinoza et al., 2011) describe 
the strong influence of tropical North Atlantic SST on hydrology into the western Amazon Basin. Thus, while tropical North Atlantic SST is warmer than usual, less rainfall and discharge is noticed in the western Amazon during austral winter and spring. For this reason, a further study on this topic taking into account the ENSO and the Atlantic influences will be undertaken in the future.

Acknowledgements. This work was conducted with funding from the SENAMHI (Ministry of Environment). Special thanks to Jhan Carlo Espinoza for his contributions in improving this document and also to Ana Gropuzzo by the translation of this article. Also, thanks to two anonymous reviewers for help to improve this paper.

\section{References}

Aceituno, P. and Montecinos, A.: Análisis de la estabilidad de la relación entre la oscilación del Sur y la precipitación en América del Sur, Bull. Inst. Fr. études Andines, 22, 53-64, 1993.

Chiew, F., Piechota, T., Dracup, J., and McMahon, T.: El Niño/Southern Oscillation and Australian rainfall, streamflow and drought: Links and potential for forecasting, J. Hydrol., 204, 138-149, 1998.

Chiew, F. H. S. and McMahon, T. A.: Global ENSO-streamflow teleconnection, streamflow forecasting and interannual variability, Hydrolog. Sci. J., 47, 505-522, 2002.

Cluis, D. and Laberge, C.: Analysis of the El Niño effect on the discharge of selected rivers in the Asia-Pacific region, Water Int., 27, 279-293, 2002.

Dettinger, M. D., Cayan, D. R., McCabe, G. M., and Marengo, J. A.: Multiscale streamflow variability associated with El Nino/Southern Oscillation, in: El Niño and the Southern Oscillation-Multiscale Variability and Global and Regional Impacts, edited by: Diaz, H. F. and Markgraf, V., Cambridge University Press, 113-146, 2000.

Espinoza, J. C., Guyot, J. L., Ronchail, J., Cochonneau, G., Filizola, N., Fraizy, P., Labat, D., Noriega, L., Oliveira, E., Ordoñez, J. J., and Vauchel, P.: Contrasting regional discharge evolutions in the Amazon basin (1974-2004): Contrasting regional discharge evolution in the Amazon Basin, J. Hydrol., 375, 297-311, 2009.
Espinoza, J. C., Ronchail, J., Guyot, J. L., Junquas, C., Vauchel, P., Lavado, W. S., Drapeau, G., and Pombosa, R.: Climate variability and extremes drought in the upper Solimões River (Western Amazon Basin): Understanding the exceptional 2010 drought, Geophys. Res. Lett., 38, L13406, doi:10.1029/2011GL047862, 2011.

Kawamura, A., McKerchar, A., Spigel, R., and Jinno, K.: Chaotic characteristics of the Southern Oscillation Index time series, J. Hydrol., 204, 168-181, 1998.

Marengo, J. A., Tomsella, J., and Uvo, C. R.: Long-term streamflow and rainfall fluctuations in tropical South America: Amazonia, East Brazil, and Northwest Peru, J. Geophys. Res., 103, 17751783, 1998.

McKerchar, A., Pearson, C., and Fitzharris, B.: Dependency of summer lake inflows and precipitation on spring SOI, J. Hydrol., 205, 66-80, 1998.

OPS: Perú: Fenómeno El Niño, 1997-1998, Organización Panamericana de la Salud, Fenómeno El Niño, 1997-1998, Washigton D.C., 2000.

Ronchail, J., Cochonneau, G., Molinier, M., Guyot, J. L., Goretti de Miranda Chaves, A., Guimarães, V., and de Oliveira, E.: Rainfall variability in the Amazon Basin and SSTs in the tropical Pacific and Atlantic oceans, Int. J. Climatol., 22, 1663-1686, 2002.

Ropelewski, C. F. and Halpert, M. S.: Global and Regional Scale Precipitation Patterns Associated with the El-Nino Southern Oscillation, Mon. Weather Rev., 115, 1606-1626, 1987.

Vuille, M., Kaser, G., and Juen, I.: Glacier mass balance variability in the Cordillera Blanca, Peru and its relation with climate and large-scale circulation, Global Planet. Change, 62, 14-28, 2008.

Waylen, P. R. and Caviedes, C. N.: El Niño and annual floods on the north Peruvian littoral, J. Hydrol., 89, 141-156, 1986.

Waylen, P. and Poveda, G.: El Nino southern oscillation and aspects of western South American hydroclimatology, Hydrol. Process., 16, 1247-1260, 2002.

Wells, L. E.: An alluvial record of El-Niño events from northern coastal Peru, J. Geophys. Res.-Oceans, 92, 14463-14470, 1987.

Xu, Z. X., Takeuchi, K., and Ishidaira, H.: Correlation between El Nino-Southern Oscillation (ENSO) and precipitation in Southeast Asia and the Pacific region, Hydrol. Process., 18, 107-123, 2004.

Yoon, J. H. and Zeng, H.: An Atlantic influence on Amazon rainfall, Clim. Dynam., 34, 249-264, 2010. 